\title{
Albanian Goods Towards European Internal Market
}

\author{
Ph.D. Ulpian Hoti \\ Chancellor, "Aleksander Moisiu" University, Albania \\ Email: ulpian.hoti@yahoo.com \\ PhD. Sokol Bana \\ Head of Department, Faculty of Human Science, "Ismail Qemali" University, Albania \\ Email: sokolbana@yahoo.it
}

\section{Doi:10.5901/ajis.2015.v4n2p455}

\begin{abstract}
The free movement of goods is one of the four fundamental freedoms guaranteed in the European Union and from which European citizens and businesses as well as other citizens outside Europe are now benefiting. It is at the heart of the EU policies. Today's free movement of goods incorporates many policies and fits smoothly into a responsible internal market which guarantees easy access to high-quality products, combined with a high degree of protection of other public interests. The free movement of goods has been a key element in creating and developing the internal market and nowadays the Albanian market as well. Albania from June 2014 is a candidate country to the EU and Albania's reform agenda under the SAA is covering areas ranging from political dialogue and regional cooperation to Community freedoms in the movement of goods, services, workers and capital, and mutual co-operation in justice and home affairs. In the context of the integration in the European Union, Albania is now fulfilling the criterion of membership in EU through the fulfillment of the Stabilization and Association Agreement (SAA). The aim of this paper is to show that free movement of Albanian's goods toward European Union, under SAA these years is in a good perspective. Articles 34-36 of the Treaty which define the scope and content of the principle by prohibiting unjustified restrictions on intra-EU trade and articles 16-45 SAA are on the focus of this study. In particular will be analyzed the free movement of goods, the harmonizing legislation, the actual rights and duties to be observed.
\end{abstract}

Keywords: free movement of goods, Stabilization and Association Agreement, Albanian goods, products etc.

\section{Introduction}

The free movement of goods is considered worldwide one of the success stories of the European project. Free movement of goods is one of the key areas for the implementation of the right to free market principles. The principle of free movement of goods implies that products must be traded freely within the European Union. In a number of sectors this general principle is complemented by a harmonized regulatory framework. Smooth implementation and proper European legislation requires sufficient administrative capacity for the notified restrictions on trade and to apply horizontal and procedural measures in areas such as standardization, conformity assessment, accreditation, metrology and market surveillance in Albania. As it is well known, the Stabilization and Association Agreement establishes a number of obligations in the field of free movement of goods. It also provides for the gradual approximation of technical regulations and standards of the EU as well as metrology, accreditation and conformity assessment procedures. Today's internal market and at the same time the free movement of goods is good for business. The internal European marketplace that was created in past decades helps EU businesses to build a strong platform in an open, diverse and competitive environment. This internal strength fosters growth and job creation in the European Union and gives EU businesses the resources they need in order to be successful in other world markets (Craig, Burga 2011). A properly functioning internal market for goods is thus a critical element for the current and future prosperity of the EU in a globalized economy (A. Rizzo - F. Di Majo, 2008).

The free movement of goods has been a key element in creating and developing the internal market and nowadays the Albanian market as well. Albania from June 2014 is a candidate country to the EU and Albania's reform agenda under the SAA is covering areas ranging from political dialogue and regional cooperation to Community freedoms in the movement of goods, services, workers and capital, and mutual co-operation in justice and home affairs. In the context of the integration in the European Union, Albania is now fulfilling the criterion of membership in EU through the 
fulfillment of the Stabilization and Association Agreement (SAA). Albania's reform agenda under the SAA is covering areas ranging from political dialogue and regional cooperation to Community freedoms in the movement of goods, services, workers and capital, and mutual co-operation in justice and home affairs.

\section{The Legal Framework of Free Movement of Goods in the EU and Under SAA}

First of all we have to establish here the general legal framework of the free movement of goods in the internal market. We have to specify at the same time the Articles of the Treaty and the secondary legislation and the SAA. Nowadays the internal market goes beyond the Treaty articles. Harmonized legislation in many areas has specified the meaning of the internal market and has thereby framed the principle of the free movement of goods in concrete terms for specific products (Gormley, 2009). The main Treaty provisions governing the free movement of goods are: Article 34 TFEU, which relates to intra-EU imports and prohibits quantitative restrictions and all measures having equivalent effect' between Member States; Article 35 TFEU, which relates to exports from one Member State to another and similarly prohibits 'quantitative restrictions and all measures having equivalent effect'; and Article 36 TFEU, which provides for derogations to the internal market freedoms of Articles 34 and 35 TFEU that are justified on certain specific grounds (Villani 2008). Articles 34-36 TFEU laid the groundwork for the general principle of the free movement of goods (Mengozzi 2010). But it is important to consider here the secondary legislation as well: Directive 98/34/EC; Regulation (EC) No 2679/98, The 'strawberry' regulation; Regulation (EC) No 764/2008, The 'mutual recognition' regulation and the Regulation (EC) No 764/2008, the 'mutual recognition' regulation'.

As regards Albania, the Stabilization and Association Agreement (SAA) with the country was signed on 12 June 2006 and entered into force on 1 April 2009. The Stabilization and Association Agreement creates a number of obligations such as establishment of a free trade area between the EU and its Member States and Albania. In this context, however, Member States has been interpreted broadly to include all the authorities of a country, be they central authorities, the authorities of a federal state or any other territorial authorities (Caka, Blockmans 2009). The Stabilization and Association Agreement creates a number of obligations in the field of free movement of goods ${ }^{2}$. It also provides for gradual alignment to EU technical regulations and standards as well as metrology, accreditation and conformity assessment procedures (Canaj, Bana 2014).

The key documents of the Albanian government in this context are: the National Strategy for Development and Integration (2007-2013); The National Plan for the implementation of the SAA (2007-2013); the Action Plan addressing the Recommendations of the EC Opinion for Albania. The Law "On standardization" was adopted in March 2008.

We can say that Albania has a good level of preparation regarding the freemovement of goods. There are established and functionalmain administrative structures, responsible for standardization, accreditation and metrology.The General Directorate of Standardization (GDS), a government department reporting to the Minister of Economy, Trade and Energy, is responsible for standardization in all fields except telecommunications. The GDS is a correspondent member of the International Organization for Standardization (ISO), an associate member of the International Electro technical Commission (IEC) and an affiliate member of both the European Committee for Standardization (CEN) and the European Committee for Electro technical Standardization (CENELEC).

During 2010 the General Directorate of Standardization (GDS) continued its preparations to apply for full membership of the European Committee for Standardization (CEN) and of the European Committee for Electro technical Standardization (CENELEC) in 2012. Currently the total number of bodies accredited conformity assessment is 39, of which 24 testing laboratories, 3 certification bodies and inspection bodies $12^{3}$. All conformity assessment bodies

\footnotetext{
${ }^{1}$ The regulation places the burden of proof on the national authorities that intend to deny market access. They must set out in writing the precise technical or scientific reason for their intention to deny the product access to the national market. The economic operator is given the opportunity to defend its case and to submit solid arguments to the competent authorities. The regulation also establishes 'product contact points' in each Member State, which provide information about technical rules on products and the implementation of the mutual recognition principle to enterprises and competent authorities in other Member States. Canaj E., Vasjari A., Free movement of Albanian goods within the European Union. New challenges in the context of integration, MJSS, vol. 4 no.6, 2013, 737-746.

${ }^{2}$ For example, according to article 26 SAA: "On the date of entry into force of this Agreement, the Community shall abolish all quantitative restrictions and measures having equivalent effect on imports of agricultural and fishery products originating in Albania. 2. On the date of entry into force of this Agreement, Albania shall abolish all quantitative restrictions and measures having equivalent effect on imports of agricultural and fishery products originating in the Community".

${ }^{3}$ www.mie.gov.al.
} 
accredited fulfilled traceability policy DA.

The adoption of European standards (ENs) as Albanian standards continued to make progress. The number of ENs adopted is 17,442 , in line with the adoption rate of $95 \%$ set for 2011 . However, the number of standards translated remains low in comparison to the number of standards adopted, since most ENs have been adopted by the cover page method. The law "On standardization" was amended in February 2011 to include the possibility of adopting and publishing standards prepared by the European Telecommunications Standards Institute (ETSI). The managing board of standardization was established and became fully operational in November 2010.

\section{Which are the Main Groups of Albanian Goods in the Context of Free Movement?}

Articles 34 and 35 TFEU and articles 16-45 SAA cover all types of imports and exports of goods and products. The range of goods covered is as wide as the range of goods in existence, so long as they have economic value: "by goods, within the meaning of the ...". Treaty, there must be understood products which can be valued in money and which are capable, as such, of forming the subject of commercial transactions'. In its rulings the Court of Justice has clarified on several occasions the proper designation of a particular product. Works of art must be seen as goods. Coins which are no longer in circulation as currency would equally fall under the definition of goods, as would bank notes and bearer cheques, although donations in kind would not. Waste is to be regarded as goods even when it is non-recyclable, but the subject of a commercial transaction. Electricity and natural gas count as goods, but television signals do not.

The latter example underlines the fact that it can be legally important to draw a distinction between goods and services. While fish share certainly goods, fishing rights and angling permits are not covered by the free movement of goods principle, but constitute the 'provision of a service within the meaning of the Treaty provisions relating to the freedom to provide services.

According to the latest data the main groups of product exported are: food, beverages, tobacco, minerals, fuels, electricity, chemical and plastically products, leather, wood manufacture and articles of paper, textile and footwear, construction materials and metals, machinery, equipment spare parts 4 . Requirements to be met by imported products as regards shape, size, weight composition, presentation, identification or putting up may force manufacturers and importers to adapt the products in question to the rules in force in the European Member State in which they are marketed, for example by altering the labeling of imported products. Given that such requirements as to the presentation of the goods are directly interlinked with the product itself, they are not considered to be selling arrangements, but as measures having equivalent effect.

According to the latest data the international trade in goods by EU countries, (March 2015) is influenced by groups: "Construction materials and metals" contributed with +8.4 percentage point, "Machinery, equipment, spare parts" contributed with +3.0 percentage point, "Food, beverages, tobacco" contributed with +1.2 percentage point, "Minerals, fuels, electricity" contributed with -8.1 percentage point, "Textile and footwear" contributed with -1.2 percentage point. The main partners of Albania to be considered in the context of free movement of goods are: Austria, United Kingdom, Germany, Italy, Spain and Croatia.

According to the INSTAT, on March 2015 the value of exports was 22 billion lekë, increasing by $4.0 \%$ compared with March 2014. On March 2015 the value of imports was 44 billion lekë, increasing by $3.9 \%$ compared with March 2014

Let's have an example:

Overall agricultural indicators of export and import

In 2014, trade volume in the agriculture and food sector was nearly 770.8 million Euros, or 5.7\% more than in 2013. Import-to-export ratio improved to 1:5:3 from 1:5:7 in 2013.

${ }^{4}$ www.instat.gov.al. 
Table 1: Foreign trade of Albania (000 Euro) - 2013/2014

\begin{tabular}{|l|c|c|c|}
\hline Description & $\mathbf{2 0 1 3}$ & $\mathbf{2 0 1 4}$ & Index 2014/2013 \\
\hline EXPORTS & $\mathbf{1 0 8 , 4 2 8}$ & $\mathbf{1 2 1 , 2 3 9}$ & $\mathbf{1 1 1 . 8 2}$ \\
\hline Export EU & 74,822 & 80,409 & 107.47 \\
\hline Export CEFTA & 20,588 & 26,317 & 127.83 \\
\hline Export other countries & 13,018 & 14,513 & 111.49 \\
\hline IMPORTS & $\mathbf{6 2 0 , 8 6 6}$ & $\mathbf{6 4 9 , 5 3 7}$ & $\mathbf{1 0 4 . 6 2}$ \\
\hline Import EU & 341,358 & 361,386 & 105.87 \\
\hline Import CEFTA & 65,027 & 78,057 & 120.04 \\
\hline Import other countries & 214,481 & 210,094 & 97.95 \\
\hline
\end{tabular}

Source: Instat

Total exports in 2014 grew by $11.2 \%$ while imports grew by $4.6 \%$ compared to 2013 . EU remains Albania's main trade partner with around $66.3 \%$ of Albanian agricultural exports (in value) going to EU markets. The EU countries account for around $55.6 \%$ of Albania's imports. CEFTA accounts for $21.7 \%$ and the rest of the world accounts for $12.0 \%$ of Albanian exports. As for imports, $12.0 \%$ originate from CEFTA countries and $32.3 \%$ from the rest of the world. Exports are maintaining the rising trend.

Chart 1: Export and import for 2013

EU-Albania bilateral trade in basic agricultural products over the period 2013-2014 is described in the table below:

Table 2: Trade of basic agricultural products EU-Albania (000 EUR)

\begin{tabular}{|c|c|c|c|}
\hline Description & $\mathbf{2 0 1 3}$ & $\mathbf{2 0 1 4}$ & Index 2014/2013 \\
\hline Export & 35,887 & 36,230 & 101.0 \\
\hline Import & 168,495 & 178,529 & 106.0 \\
\hline Turnover & 204,382 & 214,759 & 105.1 \\
\hline Balance & $-132,607$ & $-142,299$ & 107.3 \\
\hline
\end{tabular}

Source: Instat - Regime 1 (Normal)

As shown in Table 2, for 2014 the trade volume of basic products has been 214.8 million Euro, with an increase of $5.1 \%$ compared to the trade volume in 2013. This increase is mainly because of the import increase of about $6.0 \%$ and a very small increase of the exports of about 1.0\%. The increase of imports has led to deterioration of the trade balance with about $7.3 \%$ compared to 2013 as the imports constitute $83.1 \%$ of the trade volume.

The most imported group of basic agriculture products in 2014 continuous to be "sunflower, sunflower/cotton-seed oil". It had an increase of import value of about $13.7 \%$ and constitutes $7.7 \%$ of the value of the import of basic products. The other more imported groups of products were "citrus fruit, fresh or dried" and "coffee" by representing $6.9 \%$ and $6.1 \%$ of the total import value, respectively. Referring to the data, a number of main groups of products had an increase in the import (quantity and value). So, the import value of the group of products "rice" (code 1006) increased by 63\% constituting in $20144.1 \%$ of the total imports compared to $2.7 \%$ in 2013; the import value of "potatoes" increased by $64 \%$ constituting in 2014 1.9\% of the total imports compared to 1.3\% in 2013. Differently from previous years when the group of products "Meat of swine, fresh, chilled or frozen" was characterized by a decrease in import, in 2014 this group had a significant increase of about $103.4 \%$ of import value.

During year 2014, the import of group of products "wheat and meslin" decreased in quantity and in value by $48.5 \%$ and $54.8 \%$ respectively, compared to 2013. In 2014 this group constituted $3.6 \%$ of the imports compared to $8.5 \%$ in 2013 . Despite of this decrease, actually the imported quantity of "wheat and meslin" had increased and the value decreased, reflecting the fact of importing this product from other less expensive markets.

At the other hand, the processed agriculture products that Albania exported to EU markets with very few groups and very low exports value.. In 2014 the main group of products with the highest export value was "bread, biscuits, wafers, cakes" constituting $41.0 \%$ of the exports from $14.0 \%$ in 2013. The export of this group continued to increase and in 2014 it had a considerable increase of 2.8 times, in quantity and in value. 
The group products "Extracts, essences and concentrates, of coffee, tea or maté" (code 2101), even though is the second most exported, in 2014 its export values decreased by 55\%, constituting $26.6 \%$ of total processed agriculture products export from 55\% it constituted in 2013. Also, the export of another important group of products "Spirits, liqueurs, other spirit bev." continued to decrease constituting only $4.1 \%$ of the total PAPs' export from $14.7 \%$ in 2013.Notwithstanding the small amount of exports the group of products "Mineral \& aerated waters", "Non-alcoholic beverages (excl. water)" and "Vegetable material for plaiting" were characterized by a considerable increase in 2014. Actually the export of "Mineral \& aerated waters" increased by 5.5 times, of "Non-alcoholic beverages (excl. water)" by 14 times and of "Vegetable material for plaiting" by 2.5 times.

Even during 2014 the most imported products are those imported in 2013. Again, the main group of products with the highest import value was "Cigars, cheroots, cigarillos \& cigarettes" although its import decreased in quantity and value by $21.6 \%$. For 2014 this group of products constituted $27.7 \%$ of the total import, followed by groups of "non-alcoholic beverages", "bread, biscuits, wafers, cakes" and "beers made from malt "constituting respectively $13.54 \%, 9.27 \%$ and $8.90 \%$ of the total import of processed agriculture products.

Referring to livestock development in years there is stability in the number of heads, and the production of livestock products mainly in milk and meat, which occupies a specific and significant weight of income from agriculture.

Livestock farms which have operated as a mixed farm, every year more and more have been oriented toward a determined specialization of production, which has led to the increase of the number of farms that breed a significant number of certain breeds of animal, a fact that has affecting the stability of production and growth of specific products.

In terms of implementation of livestock development programs, particularly in the bovine sector, efforts has been made to set up a collection system for the animal husbandry data, which will serve to breed improvement programs in bovine breeds Holshtein and Xhers. During this period, is partly set up the data collection structure in five regions Tirana, Shkodra, Durresi, Elbasani, Fieri.

Meat production accounts for about $46.6 \%$ of livestock production where the largest share comes from the meat produced by cattle around $46 \%, 32 \%$ of small ruminants and $11 \%$ respectively, pork and poultry. For 2015 it is foreseen a $1 \%$ increase in meat production generally.

Animal genetic resources are the primary biological capital for livestock development, and are vital for food security and sustainable rural development.State budget continues to support financially conservation of animal genetic resources and especially the preservation and protection of animal breeds in danger of extinction.

\section{Conclusions}

The obligation to align its legislation with the European Legislation Chapter 1 derives from Article 70 and 75 of the SAA. These provisions oblige Albania technically to bring its national legislation in line with that of the EU, but also to ensure that it is applied and enter into force Thus, already at this stage of the pre-accession process, various organs the state should be involved in the exercise of approximation of national legislation with the acquis in force.

Moreover, when EU legislation is subject to constant development, approximation of laws would not be complete with the adaptation of legislation with the European legislation currently in force. Continuous monitoring of the developments of the EU is necessary for the pre efforts, as well as the preparation of Albania as everyday reality for future membership in the EU. In the context of the SAA, the European Partnership with Albania is the main instrument to assist the Albanian authorities in the realization of the European perspective of the country. European Partnership priority deals with time short and long term issues of free movement of goods.

It is recommended to further increase the awareness of economic operators in relation to the concepts of standards and certification and their importance in international trade; adoption and implementation of the national strategy of market supervision and approval of new legislation on consumer protection. Medium priority list includes: providing administrative capacity to implement the requirements of the SAA; progress in transposing the new approach directives and older; the creation of a market surveillance system; ensuring the proper functioning of the bodies responsible for standardization, accreditation and metrology and calibration; providing the membership with full rights in the European Organization for Accreditation.

In Albania there has been progress in the area of free movement of goods, particularly with regard to adopting EN standards as Albanian standards and in establishing the managing board of standardization. Further efforts are still needed in order to harmonize Albanian legislation with the New and Old Approach directives, as well as to align the horizontal legislation with the acquis and to build up an adequate market surveillance infrastructure. The European Commission in its conclusions of this year established that: 'In the area of free movements of goods there has been 
progress as regards standardization. Work needs to continue on legislative approximation of the acquis. Referring to the latest data, a number of main groups of products had an increase in the import (quantity and value) and it must continue for the future.

\section{References}

Canaj E., Vasjari A., Free movement of Albanian goods within the European Union. New challenges in the context of integration, MJSS, vol. 4 no.6, 2013, 737-746.

Canaj E. Bana S., E drejta e Bashkimit Europian, Onufri, 2014.

European Commission Report (2010) 5-52

European Commission Report (2011) 29-30

European Commission Report (2012) 5-6

European Commission Report (2013)10-12

National Strategy for Development and Integration (2007-2013 which establishes national The National Plan for the implementation of the SAA (2007-2013)

Action Plan for the Public Communication (2007)

Laurence W. Gormley, (2009) EU Law of free movement of goods, Oxford University Press.

Peter Olivers, (2010) Oliver on Free Movement of Goods in the European Union, Hart.

Lorna Woods, (2004) Free Movement of Goods and Services Within the European Community, European Business Law Library.

P.Craig, P.GeBurca, (2011) EU Law, Text Cases and materials.

Giuseppe Tesauro (2010), II diritto dell'Unione Europea.

Fjoralba Caka and Steven Blockmans, (2009) Implementing the Stabilization and Association Agreement in Albania: Avoiding Discriminatory Practices in the Free Movement of Goods, European Journal of Law Reform, Volume 11, Issue 4, 2009, 511-530.

T. Ballarino, Manuale breve di diritto dell'Unione Europea, Padova, 2007.

P. Barbour The European Union Hand Book, Chicago-London, 2004.

Adam Lazowski (2012), Free movement of goods, in Recent Developments in EU Law, 2 May 2012, No 13/2012.

D. Chalmas - C. Hadjiemmanuil - G. Monti - A. Tomkins; European Union Law, Cambridge, 2006.

P. Craig - G. De Bùrca, EU Law Text, Cases and materials, Oxford, 1998.

U. Draetta, Elementi di diritto comunitario, Milano, 1995.

J. P. Jacqué, Droit insititutionnel de l'Union Européenne, Dalloz, 2008.

P. Mengozzi, Istituzioni di diritto comunitario e dell'Unione Europea, Padova, 2006.

A. Rizzo - F. Di Majo, Codice dell'Unione Europea, Milano, 2008.

G. Tesauro, Diritto comunitario, Cedam, 2005.

U. Villani, Istituzioni di diritto dell'Unione Europea, Bari, 2008.

Stabilization and Association Agreement (SAA) of 12 June 2006

www.mie.gov.al

www.instat.gov.al 
